\title{
Reflections on History Workshop 17
}

\section{Neville Kirk, Paul Salveson, Ann Walker}

\author{
Manchester, England
}

History Workshop 17 was held at Manchester Polytechnic during the second weekend of November (1983). Organised into a number of "strands" - Women's History; People's History; Trade Unionism; Health; Work; the Industrial Bourgeoisie and others - the conference covered an impressive amount of ground and a variety of topics. "The Clarion Movement," "Lancashire Weavers," "the Kinder Trespass," "Unemployed Struggles on Merseyside," "Women's and Children's Health," "Imperialism and Popular Culture," "Work and Leisure," "the Economic League," "Women and the Labour Movement," "Working-Class Culture in the 1930s," and the "American Working-Class History Project" (CCNY) constituted a selection of the topics under discussion. Excellently organised, the conference attracted hundreds of people and was generally held to have been a great success. Ample opportunities were afforded for debate, the making of new contacts and the sampling of Manchester's many fine brews! Certainly this speaker enjoyed the session on After Chartism - a somewhat lengthy talk followed by a fruitful and comradely discussion concerning the character of the working class in mid-Victorian Britain.

Praise must, however, be tempered by some criticism. As highlighted below by Paul Salveson, the conference failed to attract many manual workers, the vast majority of participants being white-collar, white and college educated. It is brutally ironic that "People's History" has little or no presence in working-class Hulme which is but a stone's throw from the Poly. and University! That gap remains as wide as ever - and was hardly likely to be bridged by the highly esoteric nature of some of the talks.

To make this criticism is not to belittle the need for proper "academic" standards and "good" history, but it is to suggest that many of us (including History Workshop Journal) should make greater efforts to write and speak clearly - in a way which will have an appeal well beyond the ranks of an educated, left-wing elite. Perhaps - in the flush of enthusiasm for "people's history" - we, in England, have tended to undervalue and undersell the potentially wide appeal of labour history. After all, as socialists and trade-union members, we are part of the Labour Movement.

\section{People's History Strand}

Does "People's History" reach the "right sort of people"? "People's History" - whatever it means - is enjoying a boom in Britain. Dozens of evening classes 
looking at family history, local history and even "labour" history are pulling in the crowds throughout the country. Some of it is excellent stuff - putting working class people back on to the stage, not just union leaders or politicians but the grass roots men and women activists, the people who lived and worked, struggled and died that much history thinks are unimportant. There's also much dross: the completely uncritical local history that sees everything as terribly quaint and fascinating and that builds a big high wall between what happened in the past and what's going on today. The best of 'people's history' is being produced within organisations that aren't purely 'historical societies' but are wider, campaigning bodies: community groups - often ethnically based such as Irish and West Indian organisations, some left political groups, some local union organisations. History isn't something that's gone and is only of entertainment value: it is something that can guide struggles in the present, and give pride and self-confidence to a class or exploited group. I think this has been especially true of women's history groups which are usually much more directly linked to present day women's struggles than other forms of 'people's history'.

Having said all that - how does it fit into a report on a History Workshop conference? The People's History strand, that I was involved in organising, set out to involve local working class people in a national and sometimes esoteric historical conference. The fact that 'History Workshop' is a left wing tendency within academic history doesn't necessarily mean it is accessible or comprehensible to a working class audience!

A lot of leaflets and posters went round local libraries, union branches, community centres. We got coverage on local radio and in the local press - yet we failed to go beyond the usual History Workshop clientele - white, middle class, university educated lefties. Sessions that have drawn in audiences of $\mathbf{3 0}$ or $\mathbf{4 0}$ in local pubs - on the Pit Brow Lasses, on Working Class Writers, Struggles in Manchester factories and Battles of the Lancashire Weavers in the 30s only produced handfuls of people. While two of Manchester's most well known working class historians were giving a fascinating account of struggles at the Metro-Vicks plant in the 40s and 50s to a group of five of us, people were climbing on top of each other to listen to a 'big name' historian performing nearby. Overall, the more academic sounding the title of the talk (or should I say 'paper?) was, the bigger the audience.

Having said all that some of the People's History and Trade Union History sessions that I went to were great: plenty of discussion, no bowing down before some great 'authority' or learned academic, a really friendly atmosphere. That's the side of the conference that needs to be developed but I doubt whether 'History Workshop' is a suitable vehicle for it.

The question is - what is a suitable way to bring people together who want to use history as a tool in the political struggle and reach a broad audience? I'm convinced it can only come through local working class history groups which relate to a wider constituency - Labour and Socialist clubs and parties, unions, women's groups, community organisations. An annual conference bringing all these together 
would be a giant step forward; equally, regional conferences could be organised which wouldn't deter people who don't have the time or money to travel long distances. Of course these things won't spring from thin air - they need organisation and commitment. The regional labour history groups up and down the country could be one possible way of assisting these local groups to come together more, though they'd need a good shake-up to take on a more dynamic role.

Finally, going back to the conference again - I usually avoid plenary sessions at conferences like the plague and it was only out of organisational duty that I sat down to hear Mike Cooley, late of Lucas Aerospace now working on London's Enterprise Board, to talk on alternative products and that sort of thing. I must confess I thought I'd be bored out of my mind; instead I was enthralled. It was the most thoughtful, provocative, creative intervention on where the working class movement should be going that I've ever heard. It would be good to take his talk into every union branch, every workplace, every Labour Party organisation and really get the discussion going on what direction we should be going in. Do we want work for the sake of it - like zombies or robots, screwing door handles on cars that are going to drive out and pollute more of the countryside, kill a few people in the process, and than fall apart after five years? Mike was able to give concrete examples of socially useful products that have been made and work - like the bus that can be quickly converted to run on a railway, or new forms of machinery that enhance skill, rather than reduce it. The implications for workers are massive. Instead of being passive objects in the production process, men and women once again could become creators: making decisions, using their intelligence and skills for products that actually help the community. It was a glimpse into the future; a bit of utopia if you like, though at the same time eminently practicable. And there's nothing wrong with having utopias - we could do with having more of the old socialist vision of the $1890 \mathrm{~s}$ back into our movement.

Audrey Wise, who chaired the plenary, gave a great 'get off your backsides and use your research and study for the benefit of the movement' speech to those who hadn't gone off to get their train or coach. Let's hope it didn't all fall on deaf ears. One last thing - Ruth and Eddie Frow, whose service to working class history in Britain can't be matched, were surprised by the presentation of a sculpture in recognition of that service. They richly deserved it.

\section{Women's History Strand}

The women's strand excited a great deal of interest, so much so that it is to be hoped that this strand will be allocated larger accomodation in the future. This interest, combined with the variety and range of papers presented, created a sense of immediacy and excitement in this expanding area of historical research.

The fourteen papers presented included studies of women's involvement in Trade Unions; several detailed examinations of specific occupations in the nineteenth and twentieth centuries; the economics of women's work; and women in the 
labour movement and in fascism. Michelle Abenstern presented a fascinating paper on women's leisure in Rochdale, which avoided the pitfalls of seeing women's leisure activity as marginal, and showed, through the use of oral sources, that while women's leisure tends to exist outside or on the margins of institutionally organised activity, it was both thriving and productive at the beginning of the twentieth century.

Papers concerned with the historical representation of women were presented by Deborah Cherry, who examined visual, literary, and statistical sources with reference to the uniformity of representation of seamstresses in the mid-Victorian period; and by Madgo Dresser, whose "work in progress" on gender, nationalism, and historiography examined the way in which nationalism is often characterised in terms of female figures, such as Brittania.

Finally, the workshop on Women's History Groups provided an excellent forum for an exchange of ideas between established and emerging Women's History Groups. Such issues as the practical organization of groups to facilitate maximum access for all interested women; channels for the exchange of information; and new developments and departures were discussed at this session.

This was a well organized, stimulating and enjoyable weekend.

Further information concerning the Manchester History Workshop Conference, including available papers, can be obtained by contacting The Secretary, Department of History, Manchester University, Oxford Road, Manchester, England. 